\title{
Germination response of Treculia africana (Dacne) seeds in relation to moisture content, storage method and its duration
}

\section{E. G. Oboho* and E. L. Ngalum}

Department of Forestry and Wildlife, University of Benin, Benin-city, NIGERIA

*Corresponding author. E-mail: esoheoboho@hotmail.com

Received: March 4, 2014; Revised received: March 18, 2014; Accepted: March 30,2014

\begin{abstract}
Edible seeds of forest tree crop may be unavailable in sufficient quantity for tree planting projects and so there is need for storage. The germination response of Treculia africana seeds to storage method, duration and moisture content was investigated. Three storage methods were used namely; open basket, jute bag and air-right bottle. Moisture content over time under the storage regimes was investigated for five weeks while the storage aspect was monitored for 20 weeks. The experimental layout was completely Randomized design with three treatments and three replications. Data was analysed using one way ANOVA at $5 \%$ level of significance. Fresh seeds had $100 \%$ germination. After first week of storage, this valued decreased to $73.3 \%$ and $83.3 \%$, and drastically reduced to $3.3 \%$ and $13.3 \%$ for seeds stored in the open basket and jute bag respectively. The air-tight bottle maintained values of between $93.3-100 \%$ throughout the investigation period. There was statistical difference between storage method and duration. The moisture content of freshly extracted seeds was $36.95 \%$ and air-tight bottle maintained steady values were between 35.95 - 35.98\%; the values for the open basket and jute bag dropped to 18.97 and $20.13 \%$ respectively within five weeks and the critical moisture content of $\leq 24.16 \%$ was attained in three weeks after which there was no further germination. It is recommended that fresh seeds of $T$. africana be sown and where long term storage is needed, the air-tight bottle should be used, but resource poor farmers may employ the jute bag to store the seeds for only two weeks if seeds are meant for sowing. Further research is needed in getting appropriate storage devices for large scale storage of seeds for this important crop.
\end{abstract}

Keywords: Germination, Moisture content, Seed, Storage and duration, Treculia africana

\section{INTRODUCTION}

Forest is a vital resource for mankind and trees are the dominant features of forests. Some of the benefits that man obtains from trees and associated forest resource include timber, food, fuel wood, fodder, medicine, cultural values, nutrient recycling, and protection of soil as well as environmental amelioration. In view of the numerous social, economic and ecological values of trees to man, and continued accelerated deforestation in various countries of the world, governments have taken great interest in the management of existing natural forests and also establishing artificial forest (plantations) of timber species with little being done in respect of non timber forest products (NTPS) of the indigenous forest fruit trees that are of great value to the rural people. The provision of food and food +compliments, traditional artifacts, medicines as well as rural cottage industrial bases are therefore at risk of being lost with the erosion of native species; a situation that also means food security and poverty risk, Oboho (2011).

There is need for conservation of our indigenous forest fruit trees and encouragement of their planting by private sector that presently obtain their requirements from the wild. Many indigenous forest fruit tree species abound in Nigeria. Some of them are Gambeya albida, Treculia africana, Dacryodes edulis, Garcinia kola, Viterllaria paradoxa, Vitex doniana, Irvingia gabonensis, Balanites aegyptiaca, Ziziphus spinachristii, Dialium guineense and Spondias mombin. A total of 171 indigenous woody plants of nutritional importance were identified in the forest zone of Nigeria by Okafor (1981). Also, a total of 150 plant species in 55 families with varying applications to the local residents of Abia state were observed by Ogbonnaya (2011); of the species, 56 were used for food. The UN National Research Council has highlighted the potential of 24 wild fruits and nuts in Africa, Pye-Smith (2013). Most people relish indigenous fruit tree crops as evident from their high consumption and sales when in season. Unfortunately, this love is not matched by planting as most of these crops are still being harvested from the wild natural forest.

Large scale plantings require the use of lots of viable seeds to produce seedlings and these are often difficult to find. This difficulty has been attributed in part to the complex seed cycles of most tree species and lack of adequate knowledge of proper storage methods 
suitable for a particular seed species (Ado, 1990). Also, seeds that are eaten by man and animal may not be available in great quantity. This is particularly relevant in relation to indigenous forest fruit trees which are important in the dietary diversity of the people. Onyekwelum and Fayose (2007) were of the view that large volumes of high quality seeds are lost for planting yearly because of deficiencies in drying and storage.

One such plant of great value in Nigeria is Treculia africana, a species of great socio-economic value in South-Eastern Nigeria. With lots of seeds being lost annually due to improper storage, there is great hindrance to cultivation and conservation and predisposition to extinction. Meregini (2005) included $T$. africana in the list of endangered species of Southern Nigeria.

There is therefore need to investigate the appropriate storage method that would keep the seeds viable for planting as well as for eating over a long period of time particularly in the rural setting. A wide range of methods/devices for seed storage are available in Nigeria for the rural people. They include jute bag, pot (with glazed interior), drum, jerrican (metal plastic), tin, can, bottle, plastic bag and open baskets/ trays. It is the intention in this study to examine an appropriate one for $T$. africana seeds as applicable to resource poor farmers.

\section{MATERIALS AND METHODS}

Site: The experiment was carried out at the Department of Forestry and Wildlife Nursery in the University of Benin. The GPS(Global positioning system) location of the site is latitude $06^{\circ} 24^{\prime \prime} 060$. $^{\prime} \mathrm{N}$ and Longitude $005^{\circ} 37.397^{\prime \prime} \mathrm{E}$ and altitude $136 \mathrm{~m}$. The topography is a gentle slope and soil is sedimentary sands and sandy clay.

Treculia africana (Decne): T. africana commonly known as African breadfruit is a large evergreen tropical fruit tree of the Moraceae family and known by the different tribal groups of Southern Nigeria as Ukwa (Ibo), Afon (Yoruba) and Izevbokho (Bini). The tree reaches $30 \mathrm{~m}$ (maximum 50m) in height and $3 \mathrm{~m}$ in girth with dense spreading crown and fluted trunk, the bark is grey, smooth and thick; when cut it exudes white latex which later turns rusty red. Leaves are simple, alternate, large, about $20 \mathrm{~cm}$ (maximum $50 \mathrm{~cm}$ ) $\mathrm{x} 14 \mathrm{~cm}$ (maximum $20 \mathrm{~cm}$ ) more or less acuminate, slightly leathery, glossy above, with 9-15 pairs of up curving lateral nerves running at a wide angle to the midrib and looped close to the margin; stalk very stout, about $1.25 \mathrm{~cm}$ long (Keay et al, 1964). Flowers are greenish; both sexes in globose or slightly obvoid, very short-stalked heads. Male heads appear singly in the leaf axils and female heads on the bole and main branches. Fruits (Plate 1) are yellowish-green, rounded, large, varying in sizes on the trunk or main branches. The outer surface is rough. Each fruit contains many seeds about $1 \mathrm{~cm}$ length (Plate 2) buried in spongy pulp of the fruit. There are about 3,125 seeds per kilogram. Its wood is yellowish-brown, fine grained and flexible.

Most T. africana trees are regenerated from seeds of fallen fruits on the forest floor. The seed is the most useful part of the plant as it is highly nutritious and constitutes a cheap source of vitamins, minerals, proteins, carbohydrates and fat (Okafor and Okolo, 1974). It is variously cooked as porridge alone or mixed with other food stuff such as sorghum or roasted and eaten with palm kernel and taken as snack. The leaves are used for fodder and mulching. The pulp is eaten by nursing mothers to improve lactation. The wood is good for timber and the tree is valuable for soil conservation, windbreak and intercropping in home-gardens.

Methodology: Matured fruits of $T$. africana were procured from Ifite village in Anambra state of Nigeria. They were kept for 7 days and allowed to soften for easy extraction and cleaning of seed, followed by air-drying for two days. Clean seeds were subjected to three different storage methods namely open basket, air-tight bottle and jute bag. For each method, 30 seeds were sown per week on germination beds for observation of germination responses. Observed parameters included date of first germination of seeds, total number germinated and hence its percentage germination. Routine nursery maintenance was undertaken on the germination bed and observations were made for a twenty week period. The seed moisture content was also examined on weekly basis for 5 weeks under the three storage methods. Moisture content of seeds was determined using the method of Olomu (1995). Seeds were dried in the oven for 24 hours at $105^{\circ} \mathrm{C}$ until a constant weight was attained. The loss in weight was taken as the moisture content (MC) which was expressed as the percentage MC of the seeds. The experimental design used was completely Randomized design with three treatments and three replications per treatment. Data were statistically analysed at 5\% level of probability using analysis of variance (ANOVA) according to Alika (2006).

\section{RESULTS}

The study showed that storage method and duration affected the seed moisture content and germination of T. africana. The MC of the fresh seeds was $36.95 \%$. After one week of storage; the seed MC dropped to $35.98 \%$ in the air-tight bottle while those in the open basket and jute bag MC was $30.10 \%$ and $32.22 \%$ respectively. In the second week, there was a drop to $28.83 \%$ and $30.7 \% \mathrm{MC}$ in the open basket and jute bag respectively while in the air-tight bottle there was $35.97 \%$ MC. Further drops were observed with time and by the fifth week, the seeds in the open basket recorded $18.97 \%$, jute bag $20.13 \%$ and air-tight bottle 
Table 1. Seed moisture content in relation to storage time (weeks).

\begin{tabular}{lccccc}
\hline Storage method Day I & \multicolumn{5}{c}{ Storage duration in weeks } \\
\cline { 2 - 6 } & Wk 1 & Wk 2 & Wk3 & Wk4 & Wk5 \\
\hline Fresh & $36.95 \%$ & & & & \\
Basket & $30.10 \%$ & $28.83 \%$ & $24.16 \%$ & $20.20 \%$ & $18.97 \%$ \\
Bottle & $35.98 \%$ & $35.97 \%$ & $35.97 \%$ & $35.96 \%$ & $35.95 \%$ \\
Jute bag & $32.22 \%$ & $30.75 \%$ & $27.33 \%$ & $22.76 \%$ & $20.13 \%$ \\
\hline
\end{tabular}

$\mathrm{Wk}=$ week

Table 2. ANOVA for moisture content of T. africana in relation to storage method and duration.

\begin{tabular}{lccccc}
\hline Source & Type III sum of squares & Df & Mean square & F.cal & F.Tab \\
\hline Model & $13017.754^{\mathrm{a}}$ & 7 & 1859.679 & 189.229 & 3.84 \\
Storage period & 152.349 & 4 & 38.087 & $3.875^{*}$ & 4.46 \\
Storage method & 387.491 & 2 & 193.746 & $19.714^{*}$ & \\
Error & 78.622 & 8 & 9.828 & & \\
\hline Total & 13096.376 & 15 & & & \\
\hline
\end{tabular}

$\mathrm{a}=\mathrm{R}$ Squared - 0.994 (Adjusted R Squared - .989), *Mean difference is significant at the 0.05 level

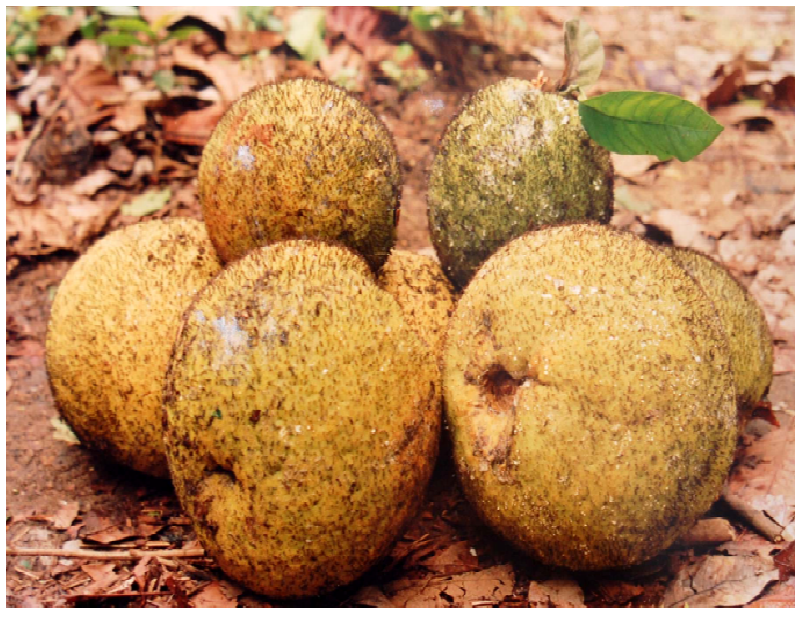

Plate 1. Showing fruits of T. africana

was $35.95 \%$ (Table 1). From the results, the critical moisture content of $T$. africana seed was $\leq 24.16 \%$; this is the point after which no further germination could occur. The seed moisture content was statistically significant in relation to storage method and duration. There was also statistical difference in moisture content between the storage methods. The variation between jute bag and open basket was not statistically different but that of the air-tight bottle differed significantly from both methods (Table 2).

Germination responses under the different storage methods varied as evident in terms of dates to germination and germination percentages. The germination of fresh seeds commenced on the $12^{\text {th }}$ day and there was a gradual increase in days to germination with duration of storage. Seeds in the open basket took 15 days to commence germination in the first week of storage, 16 and 18 days after the second and third week respectively; thereafter no further germination. Similarly, seeds in the jute bag took 15 days to commence germination in the first

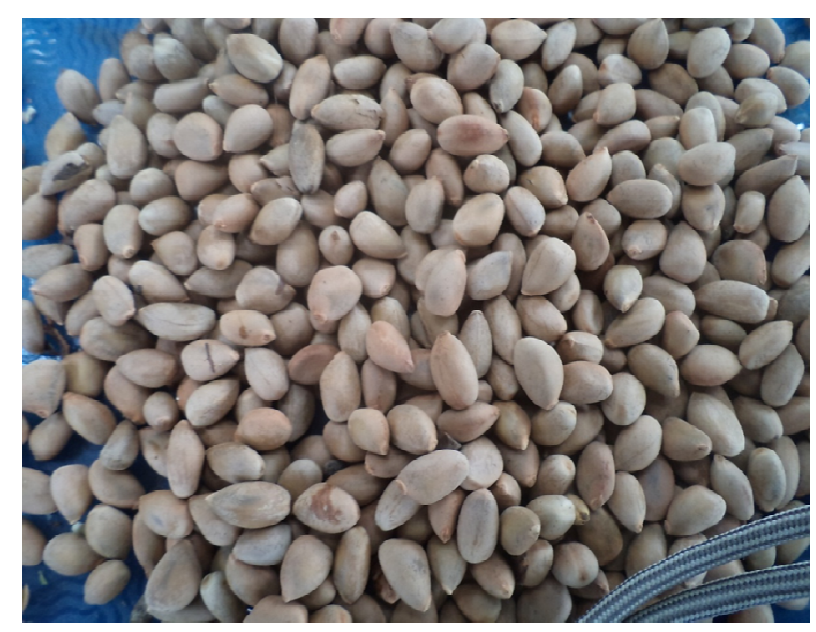

Plate 2. Showing seeds of T. africana

week, 16 and 17 days in the second and third week respectively; after which there was no more germination. Seed stored in the air-tight bottle germinated in the $13^{\text {th }}$ day in the first week and germination in all subsequent weeks of storage was attained in 14 days (Table 3).

Freshly sown seeds had $100 \%$ germination and there followed a decline in value as storage duration increased. The open basket seeds had 73.3, 23.3 and $3.3 \%$ germination in the first, second and third weeks of storage respectively after which there was no further germination. Jute bag seeds had 83.3, 33.3 and $13.3 \%$ germination in the first, second and third week respectively. The air-tight bottle had $100 \%$ germination in the first week and maintained a minimum level of $93.3 \%$ throughout the 20 weeks of investigation (Table 4) and still remained so in 36 weeks after investigation. Storage method significantly affected germination; but there was no statistical difference between values of the open basket and jute bag. There was also significant difference between 


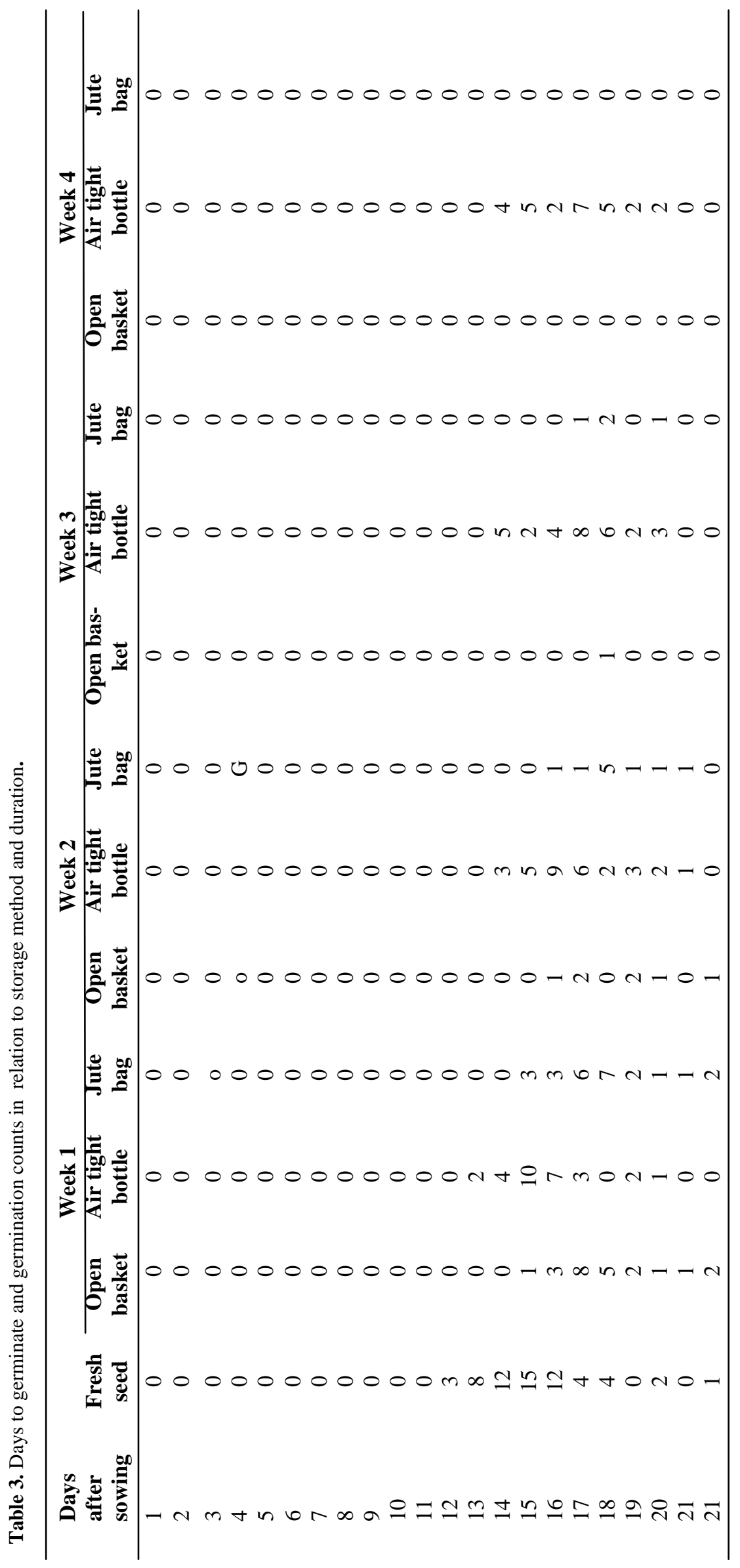


Table 4. Weekly germination $\%$ of T. africana under different storage methods.

\begin{tabular}{lcccccc}
\hline Week & $\begin{array}{c}\text { No. of } \\
\text { germination }\end{array}$ & $\begin{array}{c}\text { \% } \\
\text { germination }\end{array}$ & $\begin{array}{c}\text { No. of } \\
\text { germination }\end{array}$ & $\begin{array}{c}\text { \% } \\
\text { germination }\end{array}$ & $\begin{array}{c}\text { No. of } \\
\text { germination }\end{array}$ & $\begin{array}{c}\text { \% } \\
\text { germination }\end{array}$ \\
\hline 1 & 22 & 73.3 & 30 & 100 & 25 & 83.3 \\
2 & 7 & 23.3 & 28 & 93.3 & 10 & 33.3 \\
3 & 1 & 3.3 & 30 & 100 & 4 & 0 \\
4 & 0 & 0 & 29 & 96.3 & 0 & 0 \\
5 & 0 & 0 & 29 & 96.3 & 0 & 0 \\
6 & 0 & 0 & 30 & 100 & 0 & 0 \\
7 & 0 & 0 & 29 & 96.3 & 0 & 0 \\
8 & 0 & 0 & 30 & 100 & 0 & 0 \\
9 & 0 & 0 & 28 & 93.3 & 0 & 0 \\
10 & 0 & 0 & 28 & 93.3 & 0 & 0 \\
11 & 0 & 0 & 30 & 100 & 0 & 0 \\
12 & 0 & 0 & 30 & 100 & 0 & 0 \\
16 & 0 & 0 & 30 & 100 & 0 & 0 \\
20 & 0 & 0 & 29 & 93.3 & 0 & 0 \\
\hline
\end{tabular}

Table 5. ANOVA for germination $\%$ of $T$. africana under different storage methods.

\begin{tabular}{lccccc}
\hline Source & $\begin{array}{c}\text { Type in sum of } \\
\text { squares }\end{array}$ & Df & Mean squares & F-cal & F-tab \\
\hline Model & $12757.000^{\mathrm{a}}$ & 16 & 797.312 & 57.108 & 2.16 \\
Storage duration & 752.000 & 13 & 57.846 & $4.143^{*}$ & 2.39 \\
Storage methods & 6610.333 & 2 & 3305.167 & $238.734^{*}$ & \\
Error & 363.000 & 26 & 13.962 & & \\
\hline Total & 13120.000 & 42 & & & \\
\hline
\end{tabular}

a: R Squared $=972$ (Adjusted R Squared $=0.955)$, Implies that there is significant difference between storage method and duration

storage method and duration (Table 5) while the mean number of seeds germinating also varied with method and duration. Statistical analysis showed that storage duration had significant effect on the germination of $T$. africana seeds stored in open basket and jute bag but no effect on seeds in the air-tight bottle. The open basket and jute bag exhibited similar germination responses with duration.

\section{DISCUSSION}

The time of commencement of seed germination and germination percentages obtainable depended on the storage method and duration of storage. The longer the duration of storage, the longer it took seeds to germinate especially in the open basket and jute bag method; the air-tight bottle however maintained relatively constant germination percentage values throughout the investigation period.

The first week of storage had the highest germination percentage value irrespective of method and there was great difference between the value of the air-tight bottle and those of jute bag and open basket. The germination decreased sharply as the duration of storage increased for the air-tight bottle and jute bag. Onyekwelum and Fayose (2007) and Nuga et al. (2011) similarly found that germination started earlier in freshly sown seed. The constantly high germination percentage exhibited by seeds in air-tight bottle means that the method was able to prevent seeds from direct effects of the surrounding environment and agents of seed deterioration. Offiong et al. (2000) were of the view that the environmental and inherent properties of seeds play an important role in their ability to germinate. They opinioned that factors like storage method, duration, moisture content of seed in storage, temperature and relative humidity could cause decrease in germination percentage of seeds in storage. That the open basket and jute bag method in this study had the worst germination rating which also rapidly declined with duration is a pointer to the fact that storage method has great effect on seed longevity of this crop. Since the seeds of $T$. africana do not have hard coat, they are exposed to the vagaris of the environment affecting the embryos subsequently leading to loss of germinative power. Such situation also causes excessive and rapid physiological and biochemical changes in the seeds resulting in the early use up of food reserves in the cotyledons that culminate in reduction in germinative power. This study is corroborated by Nwoboshi (1982) who noted that seeds which do not possess hard impervious seed coats loss their viability rapidly as they are subject to 
temperature and humidity fluctuations. That the air-tight bottle method consistently maintained the highest germination percentage means that the method was able to protect the seeds against temperature and humidity fluctuations. Hence, Cobinna et al. (1990) held the view that seeds without hard seed coats such as Gliricidia sepium and $T$. africana required specialized storage conditions if they are to be maintained.

This study has shown that moisture content plays a vital role in the viability and germination of seeds. During the period of study (20 weeks) the air-tight bottle seeds maintained a steady moisture content range with a negligible $1 \%$ drop whereas seeds in the open basket and jute bag had $17 \%$ and $14.82 \%$ drop irrespectively in moisture content within the period of three weeks. This means that seeds in these two methods quickly lost their moisture content and so drying faster than seeds stored in the air -tight bottle. This is an indication of recalcitrancy in $T$. africana seed if storage method is ineffective.

The critical moisture content of $\leq 24.16 \%$ for this seed was attained in 3 weeks of storage in the exposed devices and never attained in the air-tight bottle. Offiong et al. (2000) working on the influence of storage method on the germinatability of three agroforestry tree species found that air-tight bottle and fridge methods gave the best results. They attributed their findings to steady or optimum moisture and temperature conditions for the seeds in the storage devices.

This study has shown that there is a strong relationship between seed moisture content decrease, time to germination and overall germinative potential of seed. Onyekwelum and Fayose (2007) similarly observed that seed moisture content played an important role in maintaining seed viability during storage.

T. africana seeds have been shown to be sensitive to dehydration in this study by the rapid decline in its seed moisture content in the open-basket and jute bag storage methods, the sensitivity has also affected germination ability with storage method. The rate of decline in moisture content with time in relation to the storage method could also be linked to that manifested in the germination percentages and dates of attainment. The highest germination percentages were maintained by seeds in the air-tight bottle throughout the study period while the values from the other methods were low. Steady seed moisture content in the air-tight bottle effected similarly lower germination dates whereas the dates increased as moisture content decreased in the open basket and jute bag methods. Decrease in seed moisture content means that such seed when sown would require the imbibition of more water to effect the activation and enzymatic activities in the embryo to start off metabolic activities that would activate the embryo for germination, that means more days to germination as exhibited by the seeds in the open basket and jute bag methods of storage.

\section{Conclusion}

This study has revealed that $T$. africana seed is sensitive to dehydration and storage method and time greatly affected the moisture content, germination date and percentages of the seeds sown. Fresh seeds of this species were the best for germination purpose. The open basket and jute bag methods were only able to keep seeds above the critical moisture content for three weeks and no further germinations were recorded after this period with these devices.

Germination percentages of seeds stored in the two methods declined sharply with the time, reaching very low values in the third week. On the other hand, the air -tight bottle kept the seeds in constant high moisture and germination percentage levels throughout the period of investigation (and even up 36 weeks).

Based on the results of this study, fresh seeds have been recommended for immediate sowing. Where long term storage is necessary, the air-tight bottle should be used. However, resource poor farmers needing short term storage could use the jute bag to store for a period of not more than two weeks. Further research is needed in finding appropriately storage methods for handling large quantities of this crop.

\section{REFERENCES}

Ado, S. K. (1990). Effects of storage methods on the viability of some seeds of savanna tree species. B.Sc project, Department of Forestry, Usmanu Danfodio University, Sokoto, Nigeria, pp, 74 .

Alika, J. E. (2006). Statistics and Research methods. $2^{\text {nd }}$ edition. Ambik Press, Benin-City, Nigeria pp, 366.

Cobinna, J. Kolowole, G. O. and Attakrah, A. N. (1990). Leucaena and Gliricidia seed viability and germination as influenced by storage condition. Leucaena research reports, 11:91-93.

Keay, R. W. J., Onochie, C. F. A. and Standfield, D. P. (1964). Nigerian Trees, Vol. 2. Federal Department of Forest Research, Ibadan, Nigeria, pp, 495 - 9.

Meregini, A. O. A. (2005). Some endangered plants producing edible fruits and seeds in southern Nigeria. Fruits, 60:147-153.

Nuga, O. O., Okokwo, H. and Deckor, A. (2011). Influence of storage duration on viability and germination of Treculia africana (Decne). Tree crop Journ., 5: 12-17.

Nwoboshi, L. C. (1982). Tropical Silviculture: Principles and Techniques. Ibadan University Press, Ibadan.

Oboho,E.G . (2011). The role of forest in rural food security sustenance in Nigeria. Proceedings of the $34^{\text {th }}$ Annual Conference of the Forestry Association of Nigeria, 201208.

Offiong, M. O., Oboho, G. E. and Ndaeyo, N. U. (2000). Influence of Storage methods and duration on the germinability of three agroforestry tree species. Nig. Journ. Agric.Tech., 9:30-37.

Ogbonnaya,S.(2011). The significance of non-timber forest products (NTFPS) in the rural economies of Abia state, Nigeria. Proceedings of the $34^{\text {th }}$ Annual Conference of the Forestry Association of Nigeria, 215-224.

Okafor J. C. and Okolo, H. C. (1974). Potential of some indigenous fruit trees of Nigeria. $5^{\text {th }}$ Annual Conference 
of the Forestry Association of Nigeria.

Okafor, J. C. (1981). Woody plants of nutritional importance in traditional farming systems of the humid tropics. $\mathrm{PhD}$ thesis, University of Ibadan, Ibadan.

Olomu, J. M. (1995). Monogastric animal nutrition. Moisture content determination, pp. 327

Onyekwelum, J. C. and Fayose, O. J. (2007). Effect of storage method on the germination and proximate composition of Treculia africana seed. Conference on International Agricultural Research for Development. University of Kassel-Witzerhausen and University of Gottangen, October 9 - 11, 2007, pp. 34-39.

Pye-Smith,C. (2013). Trees for life. World Agroforestry Centre, Nairobi, Kenya, pp, 160. 